\title{
PENGARUH MOTIVASI DAN MENTAL BERWIRAUSAHA TERHADAP MINAT MAHASISWA AKUNTANSI UNTUK BERWIRAUSAHA STUDI PADA MAHASISWA UNIVERSITAS AHMAD DAHLAN
}

\author{
Alvian Dhian Agung \\ Sumaryanto
}

\begin{abstract}
Effect of entrepreneurship education has been considered as one of the important factors to grow and develop interest in entrepreneurship among students. With the influence of entrepreneurship education, required an understanding of how to foster young entrepreneur potential while still in college. Several previous studies mention that the student interest in entrepreneurship is the source for the birth of future entrepreneurs. The researchers using purposive sampling. The samples used in this study were 45 students majoring in Accounting active in the UAD (Ahmad Dahlan University), class of 2009 who have followed the entrepreneurship courses given, and active semester 2013/2014. Source of data obtained from questionnaires, and then analyzed using analysis techniques using multiple linear analysis techniques and tested with the F test and t test. From the test results we concluded that the resulting regression analysis to determine the effect of motivation on student interest in accounting for entrepreneurship, and entrepreneurship does not affect the mental accounting student interest in UAD for entrepreneurship.
\end{abstract}

Keywords: motivation, mental, entrepreneurial, interests, accounting for entrepreneurship.

\section{PENDAHULUAN}

Setiap lulusan perguruan tinggi memiliki sebuah harapan untuk dapat mengamalkan ilmu yang telah diperoleh selama studi sebagai pilihan untuk berprofesi. Kenyataannya terdapat beberapa pilihan yang kemungkinan akan dialami para lulusan perguruan tinggi yang telah menyelesaikan studinya. Pertama, menjadi seorang pegawai atau karyawan pada suatu perusahaan swasta, Badan Usaha Milik Negara atau pegawai negeri. Kedua, membuka usaha sendiri (berwirausaha) dalam bidang yang sesuai dengan ilmu pengetahuan yang didapat selama di perguruan tinggi. Ketiga, menjadi pengangguran karena sulit dan sengitnya persaingan atau semakin berkurangnya lapngan kerja yang sesuai dengan latar belakang studinya.

Namun dari beberapa kemungkinan tersebut, pilihan kedua yang mungkin 
menjadi pilihan alternatif bagi lulusan perguruan tinggi. Dikarenakan pada pilihan pertama untuk menjadi seorang pegawai atau karyawan semakin sulit karena ketatnya persaingan. Demikian juga pilihan untuk menjadi pegawai pemerintah yang peluangnya semakin kecil. Pilihan untuk menjadi seorang pengangguran tentu tidak ada lulusan perguruan tinggi yang memilih untuk hal tersebut. Oleh karena itu, pilihan untuk berwirausaha pilihan yang tepat, karena dengan menjadi seorang pengusaha dapat berusaha menentukan produk sendiri, membuat motivasi baru dalam perdagangan, dan memunculkan peluang kerja bagi orang lain. Seorang wirausaha harus memiliki rasa percaya diri, mampu memanfaatkan peluang, dan mau berusaha keras untuk kehidupanya.

Menjadi seorang entrepreneur adalah sebuah pilihan untuk memenuhi kebutuhan hidup, setelah menyelesaikan tugas yang diberikan orang tua kepada anaknya untuk mencari ilmu, yaitu sekolah dan juga kuliah. Setiap tindakan selalu mempunyai motivasi yang melatar belakanginya. Menurut Kamus Besar Bahasa Indonesia (KBBI, 2005), motivasi adalah kemauan untuk berbuat sesuatu, sedangkan motif adalah dorongan. Motivasi seseorang tergantung kepada kekuatan motifnya. Mental merupakan hal yang mendasar yang dimiliki oleh seseorang. Definisi mental sendiri yaitu sikap seseorang dalam berperilaku. Manusia yang bermental wirausaha mempunyai kemampuan keras untuk mencapai tujuan dan kebutuhan hidupnya.

Menurut KBBI (2005), minat adalah kecenderungan hati yang tinggi terhadap suatu gairah atau suatu keinginan. Menurut Heri (1998) Minat adalah suatu fungsi jiwa untuk dapat mencapai sesuatu yang merupakan kekuatan di dalam dan tampak dari luar. Minat berhubungan erat dengan pikiran dan perasaan. Manusia memberi corak dan menentukan sesudah memilih dan mengambil keputusan. Perubahan minat memilih dan mengambil keputusan disebut keputusan kata hati.

Peneliti melakukan penelitian ini karena termotivasi untuk mengetahui pengaruh motivasi dan mental berwirausaha terhadap mahasiswa akuntansi untuk berwirausaha Universitas Ahmad Dahlan sebagai objek tempat penelitian, karena Universitas Ahmad Dahlan merupakan salah satu perguruan tinggi yang telah memberikan mata kuliah kewirausahaan pada sebagian besar mahasiswa di 
Universitas Ahmad Dahlan.

Mahasiswa akuntansi yang mendapat mata kuliah konsentrasi kewirausahaan dan mempelajari teori tentang kewirausahaan. Motivasi dan mental untuk berwirausaha, terjadi karena telah memahami teori tentang kewirausahaan. Mahasiswa diharapkan menjadi seorang entrepreneur setelah selesai dengan studinya di bangku kuliah. Selanjutnya peneliti lebih memusatkan objek penelitiannya kepada Mahasiswa Akuntansi di Universitas Ahmad Dahlan agar peneliti dapat melihat minat berwirausaha terutama pada mahasiswa akuntansi di UAD. Peneliti tertarik untuk melakukan penelitian mengenai pengaruh motivasi dan mental berwirausaha terhadap minat mahasiswa akuntansi untuk berwirausaha.

\section{TINJAUAN PUSTAKA DAN PENGEMBANGAN HIPOTESIS}

\section{Motivasi}

Menurut KBBI (2005), motivasi adalah kemauan untuk berbuat sesuatu, sedangkan motif adalah dorongan. Motivasi seseorang tergantung kepada kekuatan motifnya. Kebutuhan manusia dapat menjelaskan dan juga memperlihatkan seberapa besar motivasi yang dimiliki seseorang, dapat juga dilihat dari setiap perilaku seseorang untuk mencerminkan seberapa besar kekuatan motivasi yang dimiliki seseorang.

Menurut Mitchell dalam Winardi (2002) motivasi mewakili proses-proses psikologikal, yang menyebabkan timbulnya, diarahkanya, dan terjadinya persistensi kegiatan-kegiatan sukarela yang diarahkan ke tujuan tertentu. Sedangkan menurut Gray dalam Winardi (2002) motivasi adalah sejumlah proses yang bersifat internal atau eksternal bagi seorang individu, yang menyebabkan timbulnya sikap antusiasme dan persistensi dalam hal melaksanakan kegiatan-kegiatan tertentu. Motivasi menjadi entrepreneur adalah suatu dorongan dari dalam diri atau suatu dorongan yang timbul dari orang lain. Hal tersebut dapat menimbulkan pemikiran yang inovatif untuk membuat sebuah konsep usaha untuk menghasilkan keuntungan dan sangat memotivasi untuk berwirausaha. 


\section{Mental Berwirausaha}

Mental merupakan hal yang mendasar yang dimiliki oleh seseorang. Definisi mental yaitu sikap seseorang dalam berperilaku. Ciri-ciri seseorang yang mempunyai mental wirausaha memiliki tujuh kekuatan pribadi menurut Purnomo dalam Tuskeroh (2013), yaitu berkemauan keras, mempunyai kekuatan pribadi, adanya pengenalan diri, percaya diri, dan pemahaman tujuan dan kebutuhan, kejujuran dan tanggung jawab, adanya moral yang tinggi dan disiplin diri sendiri, ketahanan fisik, seperti kesehatan jasmani dan rohani, kesabaran, dan ketabahan, ketekunan dan keuletan untuk bekerja keras, pemikiran yang konstruktif dan kreatif dan berorientasi ke masa depan.

Menurut Schumpeter dalam Alma (2005) yang disebut sebagai wirausahawan adalah individu yang mendobrak sistem ekonomi yang ada dan menggerakkan perekonomian masyarakat untuk maju ke depan. Menurut Suryana (2001) kewirausahaan adalah suatu kemampuan berpikir kreatif dan berperilaku inovatif (menciptakan sesuatu yang baru dan berbeda) yang dijadikan dasar, sumber daya, kiat dan proses menciptakan nilai tambah barang dan jasa yang dilakukan dengan keberanian mengambil risiko.

Berdasarkan berbagai definisi yang telah dikemukakan oleh para ahli dapat disimpulkan bahwa kewirausahaan adalah kemampuan individu dalam menangani usaha yang mengarah pada mencari, menerapkan cara kerja baru, teknologi baru dan produk baru atau memberi nilai tambah barang dan jasa. Jadi wirausaha itu mengarah kepada orang yang melakukan usaha atau kegiatan sendiri dengan segala kemampuan yang dimilikinya. Sedangkan kewirausahaan menunjuk kepada sikap mental yang dimiliki seorang wirausaha dalam melaksanakan usaha atau kegiatan.

\section{Minat}

Menurut Heri (1998) minat adalah suatu fungsi jiwa untuk dapat mencapai sesuatu yang merupakan kekuatan di dalam dan tampak dari luar. Berdasar fungsi, minat berhubungan erat dengan pikiran dan perasaan. Perubahan minat memilih dan mengambil keputusan disebut keputusan kata hati. Sudarsono (1980), menyatakan bahwa faktor-faktor yang menimbulkan minat dapat digolongkan 
sebagai berikut:

1. Faktor kebutuhan dari dalam. Kebutuhan ini dapat berupa kebutuhan yang berhubungan dengan jasmani dan kejiwaan.

2. Faktor motif sosial. Timbulnya minat dalam diri seseorang dapat didorong oleh motif sosial yaitu kebutuhan untuk mendapatkan pengakuan, dan perhargaan dari lingkungan.

3. Faktor emosional. Faktor ini merupakan ukuran intensitas seseorang dalam menaruh perhatian terhadap sesuat kegiatan atau objek tertentu.

\section{Pengaruh Motivasi terhadap Minat Berwirausaha}

Motivasi adalah sejumlah proses yang bersifat internal atau eksternal bagi seorang individu, yang menyebabkan timbulnya sikap antusiasme atau ketertarikan dalam hal melaksanakan kegiatan-kegiatan tertentu (Gray dalam Winardi, 2002). Suatu dorongan terdiri dari percaya diri, inovatif dan kreatif, memiliki jiwa kepemimpinan, efektif dan efisien dan berorientasi pada masa depan yang mempengaruhi minat mahasiswa akuntansi untuk berwirausaha (Tama, 2010 dalam Tuskeroh, 2013).

Motivasi menjadi entrepreneur adalah suatu dorongan dari dalam diri atau suatu dorongan yang timbul dari orang lain. Hal tersebut dapat menimbulkan pemikiran yang inovatif untuk membuat sebuah konsep usaha untuk menghasilkan keuntungan. Selain itu berwirausaha dapat memberdayakan tenaga kerja atau SDM (sumberdaya manusia), bebas dalam mengelola keuangan, menjadi seorang atasan, mendapatkan hasil yang memuaskan dari kreativitas sendiri dan dari usaha sendiri, juga dapat memotivasi diri untuk berwirausaha.

H1: Motivasi berpengaruh terhadap minat mahasiswa akuntansi untuk berwirausaha.

\section{Pengaruh Mental Berwirausaha terhadap Minat Berwirausaha}

Manusia yang bermental wairausaha mempunyai keberanian diri untuk mencapai suatu tujuan dengan kemampuan keras untuk mencapai tujuan dan kebutuhan hidupnya. Ciri-ciri seseorang yang mempunyai mental wirausaha memiliki tujuh kekuatan pribadi. Menurut Purnomo (1999) dalam Tuskeroh (2013), 
mental berwirausaha yaitu sikap dalam berperilaku seseorang yang bermental wirausaha mempunyai kemauan keras, percaya diri, jujur, tanggung jawab, displin, sabar dan kreatif yang mempengaruhi minat mahasiswa akuntansi untuk berwirausaha (Setiadi 2008, dalam Tuskeroh, 2013).

Teori tersebut dapat disimpulkan bahwa mental berwirausaha adalah sebuah keberanian untuk berusaha menentukan kemakmuran, kesuksesan dan memenuhi kebutuhan jasmani dan rohani yang didapatkan dari kemampuan, pemikiran dan usaha diri sendiri. Mental berwirausaha dapat dilihat dari bagaimana seorang calon entrepreneur menghadapi sebuah tantangan baru, dan menghadapi suatu resiko yang akan di terima saat menjadi seorang entrepreneur. Pengetahuan tentang kewirausahaan yang telah dijelaskan dapat menjadi motivasi dan menumbuhkan sikap mental yang berpengaruh terhadap minat untuk berwirausaha.

$\mathrm{H} 2=$ Mental berwirausaha berpengaruh terhadap minat mahasiswa akuntansi untuk berwirausaha.

\section{METODA PENELITIAN}

\section{Populasi dan Sampel}

Populasi dalam penelitian ini adalah Mahasiswa S1 Prodi Akuntasi di Universitas Ahmad Dahlan Yogyakarta. Sampel adalah bagian dari populasi yang diambil untuk diteliti ke dalam penelitian ini. Metoda pengambilan sampel dilakukan dengan cara purposive sampling. Bentuk pengambilan sampel berdasarkan beberapa kriteria yaitu mahasiswa akuntansi aktif di UAD angkatan 2009 hingga angkatan 2011/2012 atau aktif semester genap 2013/2014, dan mahasiswa yang telah menempuh semua mata kuliah konsentrasi kewirausahaan. Penelitian ini menggunakan data primer yang diperoleh dari kuesioner yang diisi responden secara langsung atau daftar pertanyaan kepada responden di Prodi Akuntansi Universitas Ahmad Dahlan Yogyakarta.

\section{Definisi Operasional Variabel}

\section{Motivasi}

Menurut Mitchell dalam Winardi (2002) motivasi mewakili proses-proses psikologikal, yang menyebabkan timbulnya, diarahkanya, dan terjadinya persistensi 
kegiatan- kegiatan sukarela yang diarahkan ke tujuan tertentu. Sedangkan menurut Gray dalam Winardi (2002) motivasi adalah sejumlah proses yang bersifat internal atau eksternal bagi seorang individu, yang menyebabkan timbulnya sikap antusiasme dan persistensi dalam hal melaksanakan kegiatan-kegiatan tertentu. Variabel ini menggunakan kuesioner yang terdiri dari 7 butir pertanyaan. Masingmasing diukur dengan 5 skala Likert (sangat tidak setuju, tidak setuju, netral, setuju, sangat setuju).

\section{Mental Berwirausaha Mental}

Definisi mental sendiri yaitu sikap seseorang dalam berperilaku. Manusia yang bermental wirausaha mempunyai kemampuan keras untuk mencapai tujuan dan kebutuhan hidupnya. Ciri-ciri seseorang yang mempunyai mental wirausaha memiliki tujuh kekuatan pribadi menurut Purnomo dalam Tuskeroh (2013), yaitu berkemauan. Variabel ini menggunakan kuesioner yang terdiri dari 7 butir pertanyaan. Masing-masing diukur dengan 5 skala Likert (sangat tidak setuju, tidak setuju, netral, setuju, sangat setuju).

\section{Minat}

Heri (1998) memukakan bahwa minat adalah suatu fungsi jiwa untuk dapat mencapai sesuatu yang merupakan kekuatan di dalam dan tampak dari luar. Dalam menjalankan fungsinya, minat berhubungan erat dengan pikiran dan perasaan. Manusia memberi corak dan menentukan sesudah memilih dan mengambil keputusan. Selain itu memberi kepuasan ataupun mengurangi ketidakseimbangan dengan membuka suatu usaha atau bisnis (Widodo, 2005). Masing-masing diukur dengan 5 skala Likert (sangat tidak setuju, tidak setuju, netral, setuju, sangat setuju).

\section{Teknik Analisis Data}

\section{Analisis Kualitas Data}

Penelitian ini menggunakan analisis faktor konfirmatori (confirmatory factor analysis) untuk memastikan apakah alat ukur yang dibuat benar-benar menjelaskan tentang dimensi variabel. Jika factor loading dari indikator $>0,50$, maka indikator 
tersebut valid (Ghozali, 2011). Uji reliabilitas ini menggunakan reliabilitas konsistensi internal yaitu teknik Cronbach alpha $(\alpha)$ yang dibantu dengan program SPSS. Apabila nilai Cronbach alpha dari hasil pengujian > 0,60 maka dapat dikatakan bahwa konstruk atau variabel itu adalah reliabel (Ghozali, 2011).

\section{Pengujian Hipotesis}

\section{Uji Asumsi klasik}

\section{a. Uji Normalitas}

Uji normalitas data adalah alat analisis untuk mengetahui suatu data berasal dari populasi yang sama (Kurniawati, n.d 2006). Menurut Fachrudin (2011), untuk mengetahui data berdistribusi normal dapat dilihat dari uji Jarque-Bera pada program E-Views. Suatu data dikatakan berdistribusi normal jika nilai probabilitas $J-B$ lebih dari alpha $(0,05)$.

\section{b. Multikolinieritas}

Multikolinieritas adalah adanya hubungan linier antar variabel independen. Multikolinieritas dapat dideteksi dengan melihat matrik korelasi antar variabel independen. Jika terdapat korelasi yang kuat (biasanya di atas 0,80), maka dapat disimpulkan terdapat multikolinieritas (Fachrudin, 2011).

\section{c. Heteroskedastisitas}

Uji heteroskedastisitas bertujuan untuk menguji dalam model regresi terjadi ketidaksamaan variance dari residual satu pengamatan ke pengamatan lain. Suatu model yang baik adalah model yang tidak terjadi heteroskedastisitas. Mendeteksi ada atau tidaknya heteroskedastisitas dalam model regresi, peneliti akan menggunakan uji White. Kriteria pengujiannya adalah jika nilai probabilitas (chisquare) $<0,05$, maka terjadi heteroskedastisitas dan jika nilai probabilitas (chisquare) $>0,05$, maka tidak terjadi heteroskedastisitas (Kusuma dan Deny, 2012).

\section{d. Autokorelasi}

Autokorelasi adalah hubungan antara residual satu observasi dengan observasi lainnya. Setiap data residual pada suatu observasi diharapkan saling bebas dengan observasi lainnya atau tidak ada autokorelasi. Pemeriksaan terhadap dugaan adanya autokorelasi dapat menggunakan uji Breusch-Godfrey atau sering 
juga disebut uji LM (Lagrange Multiplier) dengan alat bantu program E-Views. Jika nilai probabilitas $>0,05$, maka tidak terjadi autokorelasi.

\section{Analisis Regresi Berganda}

Pengujian dalam penelitian ini menggunakan regresi linier berganda dengan program E-Views. Uji hipotesis dalam penelitian ini menggunakan regresi linier berganda. Regresi linier berganda adalah regresi yang terdapat satu variabel dependen (Y) dan lebih dari satu variabel independen (X). Model regresi linier berganda dalam penelitian ini adalah:

$$
Y=\alpha+\beta_{1} X_{1}+\beta_{2} X_{2}+\varepsilon
$$

Keterangan:

Y: $\quad$ Minat menjadi entrepreneur

B: $\quad$ Koefisien Regresi Variabel Bebas

$\mathrm{X}_{1}$ : $\quad$ Motivasi menjadi entrepreneur

$\mathrm{X}_{2}$ : $\quad$ Mental berwirausaha untuk menjadi entrepreneur

$E: \quad$ Error

\section{Uji Determinasi $\left(\mathbf{R}^{2}\right)$}

Uji determinasi pada intinya mengukur kemampuan model dalam menerangkan variasi variabel dependen. Nilai koefisien determinasi adalah antara nol dan satu. Nilai $\mathrm{R}^{2}$ yang kecil berarti kemampuan variabel-variabel independen dalam menjelaskan variasi variabel dependen amat terbatas. Nilai yang mendekati satu berarti variabel-variabel independen memberikan hampir semua informasi yang dibutuhkan untuk memprediksi variasi variabel dependen. Jika dalam suatu model terdapat lebih dari dua variabel independen, maka lebih baik menggunakan nilai adjusted $\mathrm{R}^{2}$. Hal tersebut dikarenakan nilai adjusted $\mathrm{R}^{2}$ dapat naik atau turun apabila ada penambahan variabel independen dalam model, tidak seperti $\mathrm{R}^{2}$ yang selalu meningkat apabila terjadi penambahan variable independen yang tidak mempedulikan apakah variabel yang ditambahkan tersebut berpengaruh secara signifikan terhadap variabel dependen (Ghozali, 2011). 


\section{Uji F}

Output hasil uji $\mathrm{F}$ dilihat untuk mengetahui pengaruh variabel independen terhadap variabel dependen (Gujarati, 2007). Pengambilan keputusan yaitu berdasar nilai probabilitas $(F$-Statistic $)<0.05$ atau $5 \%$ maka dapat disimpulkan minimal satu variabel independen berpengaruh terhadap variabel dependen. Namun apabila nilai probabilitas $(F$-statistic) $>0,05$ atau 5\% maka dapat disimpulkan bahwa semua variabel independen tidak berpengaruh terhadap variabel dependen.

\section{Uji t}

Uji $\mathrm{t}$ digunakan untuk mengetahui pengaruh satu variabel penjelas/independen secara individual dalam menerangkan variasi variabel dependen (Ghozali, 2011). Kriteria pengambilan simpulan atas hasil pengujian adalah probability value, apabila probability value lebih kecil dari 0,05 atau 5\% maka dapat dinyatakan bahwa variabel independen berpengaruh terhadap variabel dependen. Sebaliknya jika probability value lebih besar dari 0,05 atau 5\%, maka dapat dinyatakan bahwa variabel independen tidak berpengaruh pada variabel dependen dan hipotesis yang diajukan tidak diterima atau tidak didukung oleh data penelitian.

\section{HASIL DAN PEMBAHASAN}

\section{Uji Kualitas Data}

Berdasarkan hasil uji validitas maka dapat diketahui bahwa seluruh indicator dinyatakan valid, karena telah memenuhi kriteria loading factor lebih besar dari 0,50 .

Hasil pengujian reliabilitas berwirausaha dan minat berwirausaha mempunyai nilai Cronbach alpha masing-masing sebesar 0,899, 0,812 dan 0,668. Nilai tersebut lebih besar dari 0,60. Berdasar hasil ini, semua item pernyataan dalam kuesioner dinyatakan reliabel. 


\section{Uji Asumsi Klasik}

\section{Uji Normalitas}

Tabel 1

Uji Normalitas

\begin{tabular}{|c|c|c|}
\hline Jarque-Bera & Prob. Jarque-Bera & Alpha \\
\hline 1,341652 & 0,511286 & 0,05 \\
\hline
\end{tabular}

Sumber: Data primer, diolah (2014)

Berdasar hasil tersebut, dapat disimpulkan bahwa residual persamaan regresi pada penelitian ini berdistribusi normal. Hal ini ditunjukkan pada nilai probabilitas $J-B$ sebesar 0,511286 $(0,511286>0,05)$.

\section{Uji Multikolinieritas}

Tabel 2

Uji Multikolinieritas

\begin{tabular}{|c|c|c|c|}
\hline & MIME & MBME & MOME \\
\hline MIME & 1,000000 & $-0,389470$ & $-0,503933$ \\
\hline MBME & $-0,513626$ & 1,000000 & $-0,389470$ \\
\hline MOME & $-0,503933$ & $-0,389470$ & 1,000000 \\
\hline
\end{tabular}

Sumber: Data primer, diolah (2014)

Hasil pengujian pada tabel 2 menunjukkan bahwa antar variabel tidak terdapat hubungan yang kuat (kurang dari 0,8). Hal tersebut menyatakan bahwa tidak terdapat multikolinieritas pada model.

\section{Uji Heteroskedastisitas}

Tabel 3

Uji Heteroskedastisitas

\begin{tabular}{|l|l|c|}
\hline Probability Value & \multicolumn{1}{|c|}{ Alpha } & Keterangan \\
\hline 0,495704 & 0,05 & Tidak Terjadi Heteroskedastisitas \\
\hline
\end{tabular}

Sumber: Data primer, diolah (2014

Tabel 3 menunjukkan nilai probabilitas $(0,495704)$ lebih besar dari alpha $(0,05)$. Nilai ini menunjukkan bahwa tidak terdapat heteroskedastisitas pada model penelitian. 


\section{Uji Autokolerasi}

\section{Tabel 4}

Uji Autokolerasi

\begin{tabular}{|c|c|c|}
\hline Probability Value & Alpha & Keterangan \\
\hline 0,670626 & 0,05 & Tidak Terjadi Autokorelasi \\
\hline
\end{tabular}

Sumber: Data primer, diolah (2014)

Berdasar hasil pengujian pada tabel di atas, diperoleh nilai probabilitas sebesar 0,670626 $(0,670626>0,05)$. Dengan demikian diketahui bahwa model yang diuji tidak terdapat masalah autokolerasi.

\section{Uji Hipotesis}

\section{Koefisien Determnasi $\left(\mathbf{R}^{\mathbf{2}}\right)$}

\section{Tabel 5}

\section{Uji Koefisien Determinasi}

\begin{tabular}{|c|c|c|}
\hline Model & R Square & Adjusted $\boldsymbol{R}$ Square \\
\hline 1 & 0,272 & 0,242 \\
\hline
\end{tabular}

Sumber: Data Primer, diolah (2014)

Hasil pengujian menunjukkan nilai adjusted $R$ square sebesar 0,242, berarti bahwa variabel independen yang terdiri dari motivasi, mental berwirausaha mampu menjelaskan variabilitas variabel dependen minat menjadi entrepreneur sebesar $24,2 \%$ sementara itu sisanya $75,8 \%$ dijelaskan oleh variabel di luar penelitian ini.

\section{Uji F}

\section{Tabel 6}

Uji F

\begin{tabular}{|c|c|c|c|}
\hline Model & $\boldsymbol{F}$ & Sig. & Alpha \\
\hline Regresi & 8,050888 & 0,001097 & 0,05 \\
\hline
\end{tabular}

Sumber: Data Primer, diolah (2014)

Tabel 6 menunjukkan bahwa probability value dari model regresi yang digunakan dalam penelitian sebesar $0,001097>0,05$ atau 5\%. Hasil ini mengindikasikan bahwa minimal salah satu dari variabel independen (motivasi dan mental berwirausaha) yang dimasukkan dalam model regresi, memang memiliki pengaruh terhadap variabel dependen (minat menjadi entrepreneur). 


\section{Uji t}

\section{Tabel 7}

Uji t

\begin{tabular}{|c|c|c|c|}
\hline Variabel & Sig & Alpha & Keterangan \\
\hline MOME_X1 & 0,0100 & \multirow{2}{*}{0,05} & $\mathrm{H}_{1}$ diterima \\
\cline { 1 - 1 } \cline { 4 - 4 } & 0,2524 & $\mathrm{H}_{2}$ ditolak \\
\hline
\end{tabular}

Sumber: Data Primer, diolah (2014)

Selanjutnya untuk mengetahui variabel independen secara individual dalam menerangkan variasi variabel dependen dapat dilihat berdasarkan hasil uji t pada tabel 7, yang menunjukkan bahwa:

1. Motivasi berpengaruh terhadap minat untuk menjadi entrepreneur karena nilai probabilitas variabel motivasi 0,0100 lebih rendah dari alpha 0,05. Hal ini menunjukkan mahasiswa akuntansi yang telah menempuh mata kuliah kosentrasi kewirausahaan termotivasi untuk menjadi entrepreneur. Hasil penelitian ini konsisten dengan penelitian terdahulu yang dilakukan Eko Priyambodo (2010). Hasil pengujian diperoleh simpulan bahwa kesesuaian model analisis regresi yang dihasilkan cocok untuk mengetahui pengaruh motivasi, dan mental kewirausahaan terhadap minat mahasiswa akuntansi UPN "Veteran" Jawa Timur angkatan 2006 untuk berwirausaha.

2. Mental berwirausaha tidak berpengaruh terhadap minat untuk menjadi entrepreneur karena nilai probabilitas variabel mental berwirausaha adalah 0,2524 lebih besar dari alpha 0,05 atau 5\%. Hal ini menunjukkan mahasiswa akuntansi yang telah menempuh mata kuliah kosentrasi kewirausahaan sebagian besar belum memiliki mental berwirausaha untuk menjadi entrepreneur. Hasil penelitian ini tidak konsisten dengan penelitian terdahulu yang dilakukan Eko Priyambodo (2010). Dari hasil pengujian diperoleh simpulan bahwa kesesuaian model analisis regresi yang dihasilkan cocok untuk mengetahui pengaruh motivasi, dan mental kewirausahaan terhadap minat mahasiswa akuntansi UPN "Veteran" Jawa Timur angkatan 2006 untuk berwirausaha.

\section{SIMPULAN, KETERBATASAN, DAN SARAN}

Penelitian ini dilakukan untuk mengetahui pengaruh motivasi dan mental berwirausaha terhadap minat mahasiswa akuntansi yang telah menempuh mata 
kuliah kosentrasi kewirausahaan untuk berwirausaha atau menjadi seorang entrepreneur yang dilakukan dengan model regresi berganda manunjukkan bahwa motivasi dinyatakan berpengaruh terhadap minat mahasiswa untuk manjadi entrepreneur dan mental berwirausaha dinyatakan tidak berpengaruh terhadap minat mehasiswa untuk menjadi entrepreneur.

Penelitian ini belum dinyatakan sempurna, dan peneliti menyadari masih terdapat keterbatasan dalam proses penelitian ini. Keterbatasan tersebut yaitu jumlah kuesioner hanya 45 yang dapat diolah dari 50 kuesioner, dan adanya ketidakseriusan dari para responden yang kurang lengkap dalam mengsi kuesioner. Hal ini dapat dilihat dari sebagian kuesioner yang kembali tetapi tidak lengkap dan dianggap rusak karena tidak dapat diolah.

Berdasar keterbatasan yang ada, maka sebaiknya bagi peneliti selanjutnya menambah variabel lain yang diduga dapat berpengaruh terhadap minat mahasiswa untuk berwirausaha atau menjadi entrepreneur, seperti kesiapan diri. Selain itu peneliti selanjutnya disarankan menambah jumlah kuesioner atau selain menyebar kuesioner juga harus melakukan wawancara langsung kepada para narasumber, agar dapat menyempurnakan penelitian ini.

\section{DAFTAR PUSTAKA}

Buchari, Alma. 2005. Kewirausahaan untuk Mahasiswa dan Umum. Bandung: PT Alfabeta.

Buchari, Alma. 2007. Menejemen Perusahaan \& Pemasaran Jasa. Bandung: PT Alfabeta.

Buchari, Alma. 2009. Kewirausahaan. Bandung: PT Alfabeta.

Fachrudin, Kurniawan A. 2011. Training_E-Views.pdf, Didapatkan: Blog: Kalifach.staff.uad.ac.id (10 desember 2013).

Ghozali, Imam. 2011. Aplikasi Analisis Multivariate dengan Program IBM SPSS 19. Semarang: Penerbit Universitas Diponegoro.

Gujarati, Damodar. 2007. Dasar Ekonometrika. Jakarta: Penerbit Erlangga. 
Indarti N. 2008. Intensi Kewirausahaan Mahasiswa: "Studi Perbandingan antara Indonesia, Jepang, dan Norwegia" Jurnal Ekonomi dan Bisnis Indonesia. Vol.23, No.4.

Indriantoro, Nur dan Bambang Supomo. 2002. Metodologi Penelitian Bisnis. Yogyakarta: BPFE UGM.

Kurniawati, Indah. 2006. Modul Pengolahan Data Elektronik. Mengolah Data Statistik dengan SPSS 11,5. Yogyakarta: Universitas Ahmad Dahlan.

Kusuma, Desta R, dan Deny Ismanto. 2012. Modul Praktikum Eviews. Yogyakarta: Universitas Ahmad Dahlan.

Priyambodo, Eko. 2010. Pengaruh Motivasi dan Mental Kewirausahaan terhadap Minat Mahasiswa Akuntansi untuk Berwirausaha. Skripsi, UPN "Veteran". Jawa Timur.

Purwanto, Heri. 1998. Pengantar Perilaku Manusia untuk Keperawatan. EGC. Jakarta.

Santoso, Singgih. 2003. Panduan Lengkap Menguasai SPSS. Jakarta: Elex Media Komputindo.

Sekaran, Uma. 2006. Research Methods For Business. Jakarta: Salemba Empat.

Sudarsono, 1980. Faktor-faktor yang Menimbulkan Minat. Jakarta.

Sugiyono. 2008. Statistika untuk penelitian. Alfa Beta. Bandung.

Sumarjo, Hendro. 2010. Pengaruh Karakteristik Pemerintah Daerah terhadap Kinerja Keuangan Pemerintah Daerah. Skripsi. Surakarta: Universitas Sebelas Maret.

Suryana. 2001. Kewirausahaan. Jakarta: Salemba Empat.

Susanto, Adi. 2009. Kewirausahaan. Jakarta: Ghalia Indonesia.

Tuskeroh. 2013. Pengaruh Motivasi dan Mental Berwirausaha pada Mahasiswa Akuntansi Universitas Maritim Raja Ali Haji. Skripsi. Universitas Maritim 
Raja Ali Haji, Kep.Riau.

Widodo, W Drajad. 2005. Jendela Cakrawala Kewirausahaan. Bogor: IPB Press.

Winardi, J. 2002. Motivasi dan Pemotivasian dalam Manajemen. Jakarta: PT. Raja Grafindo Persada. 